\title{
Principal's Strategy for Instructional Quality
}

\author{
Juhaini \\ SMP Negeri 1 Banyuasin III \\ Email: juhaini1975@gmail.com \\ Edi Harapan \\ Universitas PGRI Palembang, Indonesia \\ e-mail: ehara205@gmail.com \\ Nila Kesumawati \\ Universitas PGRI Palembang, Indonesia \\ e-mail: nilakesumawati@yahoo.com \\ Article History: Received on 7 November 2021, Revised on 10 January 2022 \\ Published on 25 January 2022
}

\begin{abstract}
This study is to outline the Principal's Strategy for Improving Learning Quality at SMPN 1 Banyuasin III Banyuasin Regency. This study employs a qualitative approach. Teachers from SMP Negeri 1 Banyuasin III participated in the study as informants. In this study, data were gathered through interviews, observation, and documentation. The study's findings indicate that the principal's strategy for improving the quality of learning at SMPN 1 Banyuasin III, Banyuasin III Regency is quite good, but there are still several constraints, such as teachers who are not linear with their teaching tasks, low teaching motivation, and limited infrastructure.
\end{abstract}

Keywords: Quality, Strategy, Instruction

\section{A. Introduction}

School education must be tailored to the requirements of the community. To produce excellent human resources, education in schools must be carefully handled. Education management and development are intertwined with school administration (Purwanto, 2020). According to Ningsih et al (2020), the achievement of educational goals jointly set by the school community necessitates effective, conducive, and harmonious school conditions among education personnel in schools, including school principals, teachers, administrative staff, and parents/communities, each of whom has a significant role in achieving organizational goals (Ningsih et al, 2020).

Principals are said effective if they grasp the school's existence as a complex and distinct organization and are able to carry out the principal's function as a supervisor charged with leading the school. The leader must treat individuals compassionately in order for the process to function properly. Humans are constantly impacted by many characteristics, such as qualities, attitudes, values, wants, and interests, which affect their leadership position as well as their job (Fahmi, 2017).

Furthermore, according to Suharsaputra (2018), leadership is a continuous pattern of conduct that the leader applies via other individuals, namely through the behavior displayed by the leader while influencing others, as viewed by others. Mulyasa (2013) and (2017) expressed the 
Volume 3 (1) 2022

E-ISSN: 2723-6919 P-ISSN: 2746-0827

same thing, school principal would be able to transfer some values such as emphasis on groups, support for teachers and employees, tolerance for risk, changing criteria, and so on, whereas employees will build a perspective. Subjectively addressing the fundamental values that exist in the organization in accordance with the ideals that the leader wishes to communicate via his leadership style.

The principal must be able to create a work environment in which his subordinates will always work professionally. Not for personal benefit, but to achieve individual objectives in the company in order to increase subordinates' job performance and achieve corporate goals more effectively and efficiently (Hendarman, 2018).

The accomplishment of educational goals is greatly dependent on the principal's leadership abilities and knowledge as a supervisor and one of the educational leaders. Because the principal is a professional official in charge of managing all organizational resources and partnering with instructors to educate kids in order to achieve educational goals. It is simple to do with the principal's professionalism as a supervisor for the professional development of education personnel because, according to his function, the principal understands the needs of the school he leads so that teacher competence is not only based on the competencies he previously had, but also increases and develops well so that teacher professionalism is realized (Joko, 2018).

Based on the first observations at SMP Negeri 1 Banyuasin III in Banyuasin Regency, information was received from the curriculum representative that SMP Negeri 1 Banyuasin III was a reference school created in 1978 and began functioning in 1980. There were 50 instructors involved in the learning process, including 28 civil servant teachers and 22 honorary teachers. There are 21 civil servant instructors and 7 civil servant teachers who do not yet have educator credentials among the 28 civil servant teachers who currently have education certificates. It is also supported by 16 educational staff members.

So far, the Principal of SMP Negeri 1 Banyuasin III has implemented the following techniques to improve the quality of learning: (1) incorporating teacher training, such as participation in MGMP activities, workshops, and in-house training; however, not all teachers are included. To follow these exercises, they should be used in a rotating fashion; (2) finish the learning infrastructure, such as the books in the library. However, owing to limited school budgets, it has not been executed as planned; (3) delivering infocus for each class; however, only three courses have been achieved, leaving 21 classes without infocus.

According to the curriculum spokesperson, not all instructors who teach have IT abilities, and the teacher's discipline is not linear with the topic of study being taught. Every teacher should be disciplined in the disciplines that they teach. There are still instructors who give learning materials without the use of teaching aids; teachers should present learning materials with the assistance of teaching aids so that the learning outcomes supplied to students are more effective and efficient.

\section{B. Methods}

This study employs qualitative research methodologies, namely field research, which is conducted directly in the field to acquire the essential data. Teachers from SMP Negeri 1 Banyuasin III were interviewed for this study. In this study, data was gathered through 
Volume 3 (1) 2022

E-ISSN: 2723-6919 P-ISSN: 2746-0827

interviews, observation, and documentation. The data was then evaluated using triangulation rules.

\section{Results and Discussion}

Based on the research findings regarding the school principal's guidance in improving the quality of learning at the SMP Negeri 1 Banyuasin III, an overview of the principal's strategy in improving the quality of learning at SMP Negeri 1 Banyuasin III, was developed for a oneyear school work program divided into two, namely a work program for one semester and an annual work program. Furthermore, the principal's method is to give assistance to teachers in making lesson plans, planning learning according to the curriculum, carrying out learning, evaluating, and following up on the learning process that has been carried out. Another strategy used by school principals is to organize and assist staff in formulating teaching improvements. Principals can foster trust in teachers and staff members, assist and collaborate with teachers in advancing supervision programs, encourage and guide teachers and staff to take responsibility for carrying out their duties (Atik, 2017; Muslikhah, 2018).

The following problems are impeding the implementation of the principal's strategy to increase learning quality at SMP Negeri 1 Banyuasin III: (1) there are still instructors who are not linear with their teaching assignments. There are also teachers who arrive late and personnel who are unresponsive in completing their duties; and (2) the difficulties in establishing contact owing to the Covid-19 pandemic condition. Furthermore, the Principal frequently visits the Education Office to attend meetings and other extracurricular events. (3) the teacher's lack of preparedness in submitting reports such as the results of student learning evaluations; (4) teachers' and staff's lack of sense of responsibility in carrying out their duties; (5) a lack of funds from schools to complete supporting infrastructure in the learning process, such as the still low Hotspot network, increasing the number of unrealized computers, increasing the number of unrealized book collections in libraries, and adding teacher handbooks as learning tools that have not been achieved, as well as expanding the quantity of props; (6) directions and guidance that have been conveyed to teachers and staff to add insight into technology, teachers and staff are hesitant to take computer courses due to time constraints, so that when filling out student reports is done through the teacher's E-Raport program application and staff find it difficult to input existing grades, and existing media and educational facilities in schools are insufficient; (7) getting involved in extracurricular activities as a principal; (8) At school, the bustle of each individual in everyday activities becomes an impediment to establishing collaboration with the community (Muslim et al, 2020).

According to the findings of research conducted through interviews with the principal of SMP Negeri 1 Banyuasin III, (1) the principal organizes the school by creating an organizational structure, assigning staff according to their respective disciplines, and assigning the duties and functions of each staff in the process of implementing the work. Furthermore, the principal noted that one of the challenges was that there were still instructors who were not linear in their teaching assignments. There are also professors that arrive late and personnel who are unresponsive when it comes to completing homework; (2) The principal must grasp the principal's key roles and obligations, and then put them into practice by setting a good example for subordinates and offering advice to teachers and school staff members.

Furthermore, the principal noted that the difficulty in establishing contact owing to the status of the covid 19 epidemic scenario was an impediment to building trust in themselves, 
Volume 3 (1) 2022

E-ISSN: 2723-6919 P-ISSN: 2746-0827

instructors, and school staff members. Furthermore, owing to the workload outside the school; (3) The administrator must have expertise in cultivating and directing subordinates. To progress the supervision programs carried out by the principal, it is necessary to plan supervision activities and review the outcomes of the supervision in order to identify any inadequacies in the programs that have been completed (Nuraisah, 2015).

The unpreparedness of the teacher in submitting reports such as the results of student learning evaluations is an impediment faced by the principal; (4) the school principal he provides guidance to teachers and all staff by holding regular monthly meetings and exchanging opinions on problems that exist in schools faced by teachers and administrative staff, so that they can be solved and solutions are sought together with an emphasis on responsibility. Furthermore, the principal explained that the inhibiting factors for teachers and being responsible for school staff were a lack of sense of teachers and staff in carrying out their duties; (5) the principal in improving teachers' teaching ability by sending teachers to participate in MGMP activities, seminars, workshops, IHT, and other activities that add insight to teachers in teaching with the goal of increasing teachers' competence (Murtafiah, 2015).

Based on the research findings and observations, it is known that in terms of facilities and infrastructure, the condition of the school at SMP Negeri 1 Banyuasin III is good, the teacher's room is good, the study room is good, the student desks and chairs are good, the UKS room is good, good library space, good prayer room, good school canteen, good sports equipment, good art equipment, good field, warehouse is not good. Furthermore, the results of the researchers' observations on teachers at SMP Negeri 1 Banyuasin III in making the RPP can be said to be quite good; the RPP made according to the curriculum can be said to be quite good; the evaluation carried out is quite good; and the teacher's handbook is quite good. Based on the results obtained from documentation data, where the data were used to supplement the research data, such as: (1) principal interview guidelines; (2) teacher interview guidelines; (3) the results of the principal's interview; (4) the results of interviews with homeroom teachers; (5) research permit from the Postgraduate Program at PGRI Palembang University; (6) research permit from the Banyuasin Regency Education and Culture Office; and (7) research permit from the Banyuasin Regency Education and Culture Office.

According to Mulyasa (2013), a leader's ability to raise the professionalism of his subordinates is influenced by a number of elements. First, the leader addresses his subordinates' concerns about the efficacy of the task. Second, leaders give their personnel with the necessary training, direction, and support (Listiningrum et al, 2020; Suratman et al, 2020; Maryati et al, 2020). The accomplishment of educational goals is greatly dependent on the principal's leadership abilities and knowledge as a supervisor and one of the educational leaders. Because the principal is a professional official in charge of managing all organizational resources and partnering with instructors to educate kids in order to achieve educational goals. It is simple to do with the principal's professionalism as a supervisor for the professional development of education personnel because, according to his function, the principal understands the needs of the school he leads so that teacher competence is not only based on the competencies he previously had, but also increases and develops well so that teacher professionalism is realized (Rusmida et al, 2020; Yusutria, 2016).

Based on the finding, Mardalena et al, (2020) reinforces the study where the findings of this study affect each variable. Furthermore, this research contributes to the present research study in which the principal's academic supervision is connected to the principal's approach in order 
Volume 3 (1) 2022

E-ISSN: 2723-6919 P-ISSN: 2746-0827

to promote learning quality performance (Nurul, 2014; Lisliana et al, 2020; Desrina et al, 2020).

\section{Conclusion}

According to the results, the principal's strategy for improving the quality of learning at SMPN 1 Banyuasin III was quite good, but there were still several constraining factors, such as teachers who were not linear with their teaching tasks, low teaching motivation, and limited infrastructure.

\section{E. Acknowledgement}

Thank to the Principal of SMP Negeri 1 Banyuasin III, Rector Universitas PGRI Palembang, Director of Graduate Program and friends of graduate program educational management Universitas PGRI Palembang who have supported us to do this project.

\section{References}

Atik, M. W. (2017). Upaya Kepala Sekolah dalam Meningkatkan Profesionalisme Guru di MI Mamba'ul Huda Al-Islamiyah Ngabar Ponorogo [The Principal's Efforts in Improving Teacher Professionalism at MI Mamba'ul Huda Al-Islamiyah Ngabar Ponorogo]. Jurnal Manajemen Pendidikan, 2(1), 118-133.

Desrina, D., Fitria, H., \& Mulyadi, M. (2020). The Relationship between Principal Supervision and Interpersonal Communication with the Work Ethic of Teachers. Journal of Social Work and Science Education, 1(2), 161-167. https://doi.org/10.52690/jswse.v1i2.45

Fahmi, M. Z. (2017). Upaya Kepala Sekolah dalam Meningkatkan Profesionalisme Guru di Madrasah Tsanawiyah Negeri Babat [Principal's Efforts in Improving Teacher Professionalism at Madrasah Tsanawiyah Negeri Babat]. Jurnal Manajemen dan Administrasi Pendidikan, 3(1), 209-223.

Hendarman., \& Rohanim. (2018). Kepala Sekolah Sebagai Manajer Teori dan Praktik [Principal as Manager of Theory and Practice]. Bandung: Remaja Rosdakarya.

Joko, M. (2018). Strategi Kepala Sekolah dalam Meningkatkan Mutu Guru di Sekolah Menengah Pertama (SMP) Negeri 1 Cawas Klaten [Principal's Strategy in Improving Teacher Quality at State Junior High School (SMP) 1 Cawas Klaten]. Jurnal Manajemen Pendidikan, 2(2),144-160.

Lisliana, L., Fitria, H., \& Rohana, R. (2020). The Implementation of Class Supervision and Its Positive Impact. Journal of Social Work and Science Education, 1(2), 146-160. https://doi.org/10.52690/jswse.v1i2.43

Listiningrum, H. D., Wisetsri, W., \& Boussanlegue, T. (2020). Principal's Entrepreneurship Competence in Improving Teacher's Entrepreneurial Skill in High Schools. Journal of Social Work and Science Education, 1(1), 87-95. https://doi.org/10.52690/jswse.v1i1.20 
Volume 3 (1) 2022

E-ISSN: 2723-6919 P-ISSN: 2746-0827

Mardalena., Arafat, Y., \& Fitria, H. (2020). Pengaruh Supervisi Akademik dan Kompetensi Profesional Guru terhadap Kinerja Guru di Sekolah Menengah Atas Negeri di Kecamatan Tanjung Raja [The Effect of Academic Supervision and Teacher Professional Competence on Teacher Performance in Public High Schools in Tanjung Raja District]. Jurnal Manajemen Pendidikan, 9(1), 104-114.

Maryati, E., Fitria, H., \& Rohana, R. (2020). The Influence of Principal's Leadership Style and Organizational Culture on Teacher's Performance. Journal of Social Work and Science Education, 1(2), 127-139. https://doi.org/10.52690/jswse.v1i2.38

Mulyasa, E. (2013). Manajemen dan Kepemimpinan Kepala Sekolah [Principal Management and Leadership]. Jakarta: Bumi Aksara.

Mulyasa, E. (2017). Kepemimpinan Kepala Sekolah [Principal Leadership]. Bandung: Remaja Rosdakarya.

Murtafiah, S. (2015). Peranan Kepala Sekolah dalam Meningkatkan Profesionalisme Guru di MIN Panjang Ambarawa [The Principal's Role in Improving Teacher Professionalism at MIN Panjang Ambarawa]. Jurnal Manajemen Pendidikan, 2(2), 115-129.

Muslikhah. (2018). Peran Kepala Sekolah Sebagai Supervisor dalam Mengembangkan Profesionalisme Guru di SD Negeri 02 Gawanan [The Principal's Role as Supervisor in Developing Teacher Professionalism at SD Negeri 02 Gawanan]. Jurnal Manajemen Pendidikan, 3(2), 223-237.

Muslim, B., Harapan, E., \& Kesumawati, N. (2020). Kepemimpinan Kepala Sekolah dalam Meningkatkan Mutu Pendidikan di SMA Negeri 1 Indralaya Selatan [Principal's Leadership in Improving the Quality of Education at SMA Negeri 1 Indralaya Selatan]. Jurnal Intelektualita: Keislaman, Sosial, dan Sains, 9(1), 149-158.

Ningsih., Harapan, E. \& Destiniar. (2020). Pengaruh Komite Sekolah dan Kepemimpinan Kepala Sekolah Terhadap Peningkatan Mutu Pendidikan [The Influence of School Committees and Principal Leadership on Education Quality Improvement]. JMKSP (Jurnal Manajemen, Kepemimpinan, dan Supervisi Pendidikan, 5(2), 168-174.

Nuraisah. (2015). Strategi Kepala Sekolah Dalam Peningkatan Mutu di SD Negeri 1 Peukan Bada Aceh Besar [Principal's Strategy for Quality Improvement at SD Negeri 1 Peukan Bada Aceh Besar]. Jurnal Administrasi Pendidikan, 3(3), 118-126.

Nurul, L. I. (2014). Peran Kepala Sekolah dalam Meningkatkan Profesionalisme Guru di Sekolah Menengah Pertama (SMP) Muhammadiyah 3 Kaliwungu dan SMP Muhammadiyah 6 Kendal [The Principal's Role in Improving Teacher Professionalism at Muhammadiyah 3 Kaliwungu Junior High Schools and Muhammadiyah 6 Kendal Middle Schools]. Jurnal Manajemen Pendidikan, 3(1), 57-72.

Purwanto, N. A. (2020). Peranan Kepala Sekolah dan Guru dalam Pendidikan Karakter Bangsa di SMK Dalam Mewujudkan Jati Diri Bangsa [The Role of Principals and Teachers in National Character Education in Vocational Schools in Realizing National Identity]. Istoria Jurnal Pendidikan dan Sejarah, 16(1) 
Rusmida, S. Lian, B. Puspitasari, A. (2020). Strategi Kepala Sekolah dalam Mengembangkan Kompetensi Profesional Guru. JMKSP (Jurnal Manajemen, Kepemimpinan, dan Supervisi Pendidikan), 5(2), 168-174.

Suharsaputra. (2018). Supervisi Pendidikan (Pendekatan Sistem Berbasis Kinerja) [Education Supervision (Performance Based Systems Approach)]. Bandung: Refika Aditama.

Suratman, S., Arafat, Y., \& Eddy, S. (2020). The Influence of Principal's Leadership and Teacher's Competence toward Teacher's Performance in Indonesia. Journal of Social Work and Science Education, 1(2), 96-104. https://doi.org/10.52690/jswse.v1i2.32

Yusutria. (2016). Profesionalisme Guru dalam Meningkatkan Sumber Daya Manusia [Teacher Professionalism in Improving Human Resources]. Jurnal Manajemen Pendidikan, 2(3), 105-112. 